\title{
Volcanic synchronisation between the EPICA Dome $C$ and Vostok ice cores (Antarctica) 0-145 kyr BP
}

\author{
F. Parrenin ${ }^{1,2}$, J.-R. Petit ${ }^{2}$, V. Masson-Delmotte ${ }^{3}$, E. Wolff ${ }^{4}$, I. Basile-Doelsch ${ }^{5}$, J. Jouzel ${ }^{3}$, V. Lipenkov ${ }^{6}$, \\ S. O. Rasmussen ${ }^{7}$, J. Schwander ${ }^{8}$, M. Severi ${ }^{9}$, R. Udisti ${ }^{9}$, D. Veres ${ }^{2,10}$, and B. M. Vinther ${ }^{6}$ \\ ${ }^{1}$ Laboratoire Chrono-Environnement, UMR6249, Besançon, France \\ ${ }^{2}$ Laboratoire de Glaciologie et Géophysique de l'Environnement, UMR5183 - CNRS, Grenoble, France \\ ${ }^{3}$ Laboratoire des Sciences du Climat et de l'Environnement, Gif-sur-Yvette, France \\ ${ }^{4}$ British Antarctic Survey, Cambridge, UK \\ ${ }^{5}$ Centre Européen de Recherche et d'Enseignement des Géosciences de l'Environnement, Aix-en-Provence, France \\ ${ }^{6}$ Arctic and Antarctic Research Institute, St Petersburg, Russia \\ ${ }^{7}$ Centre for Ice and Climate, Niels Bohr Institute, University of Copenhagen, Copenhagen, Denmark \\ ${ }^{8}$ Physics Institute, University of Bern, Bern, Switzerland \\ ${ }^{9}$ Department of Chemistry, University of Florence, Florence, Italy \\ ${ }^{10}$ Institute of Speleology, Romanian Academy, Cluj-Napoca, Romania \\ Correspondence to: F. Parrenin (parrenin@ujf-grenoble.fr)
}

Received: 21 October 2011 - Published in Clim. Past Discuss.: 1 December 2011

Revised: 11 April 2012 - Accepted: 1 May 2012 - Published: 8 June 2012

\begin{abstract}
This study aims at refining the synchronisation between the EPICA Dome C (EDC) and Vostok ice cores in the time interval $0-145 \mathrm{kyr}$ BP by using the volcanic signatures. 102 common volcanic events were identified by using continuous electrical conductivity (ECM), di-electrical profiling (DEP) and sulfate measurements while trying to minimize the distortion of the glaciological chronologies. This is an update and a continuation of previous works performed over the $0-45 \mathrm{kyr}$ interval that provided 56 tie points to the ice core chronologies (Udisti et al., 2004). This synchronisation will serve to establish Antarctic Ice Core Chronology 2012, the next synchronised Antarctic dating. A change of slope in the EDC-depth/Vostok-depth diagram is probably related to a change of accumulation regime as well as to a change of ice thickness upstream of the Lake Vostok, but we did not invoke any significant temporal change of surface accumulation at EDC relative to Vostok. No significant phase difference is detected between the EDC and Vostok isotopic records, but depth shifts between the Vostok 3G and 5G ice cores prevent from looking at this problem accurately. Three possible candidates for the Toba volcanic super-eruption $\sim 73 \mathrm{kyr}$ ago are suggested in the Vostok and EDC volcanic records. Neither the ECM, DEP nor the sulfate fingerprints for these 3 events are significantly larger than many others in the records.
\end{abstract}

\section{Introduction}

Ice cores drilled in polar areas are natural archives of past environmental and climatic conditions on the Earth. They can reflect past atmospheric composition and climatic variability for time periods spanning up to several hundreds of millennia in Antarctica (Petit et al., 1999; EPICA community members, 2004; Jouzel et al., 2007) with time-resolution higher than annual for at least the last $60 \mathrm{kyr}$ in some Greenland sites (Vinther et al., 2006; Svensson et al., 2008). However, in order to interpret such records in a paleoclimatic context, there is the need to constrain the age duration of the former climatic events recorded in the ice matrix (e.g. water isotopes, chemical proxies, dust) or in the gaseous species trapped within the ice.

Numerous strategies are currently applied to dating the ice matrix and the gas phase in ice cores: (i) wiggle matching of ice core records to insolation time series (i.e. orbital tuning) (e.g. Waelbroeck et al., 1995; Parrenin et al., 2004; Dreyfus et al., 2007; Kawamura et al., 2007); (ii) wiggle matching of ice core records to other dated paleo-archives such as ice, marine or terrestrial cores (e.g. Blunier and Brook, 2001; Waelbroeck et al., 2008); (iii) identification of dated horizons such as tephra layers, sulfate spikes or cosmogenic radionuclides spikes (e.g. Castellano et al., 2005; Narcisi et al., 2006; 


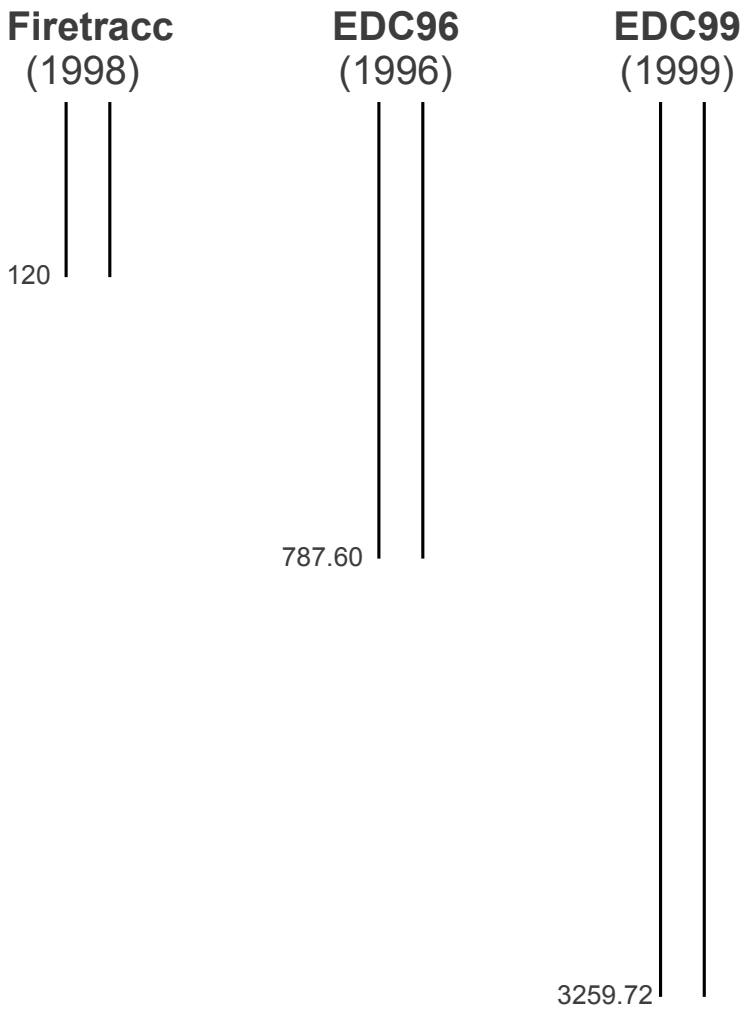

Fig. 1. Scheme of the different EDC ice cores. The depths indicated are the maximum logging depths.

Severi et al., 2007; Raisbeck et al., 2007); (iv) counting of annual layers (e.g. Svensson et al., 2008 and references therein) and (v) ice flow modelling (e.g. Parrenin et al., 2007a; Salamatin et al., 2009a), combined with firn densification modelling to estimate the ice-gas age difference $(\Delta$ age) (Goujon et al., 2003; Salamatin et al., 2009b).

Despite these efforts, when comparing records from different sites, even on the same ice sheet, age offsets always appear. The first step toward the construction of a common age model for ice cores is the synchronisation between glaciostratigraphies, i.e. the relative matching of profiles obtained within the same drill site (over distances from a few meters to kilometers) and among different drilling sites.

The drilling of ice sheets and the recovery of continuous ice sections is indeed not a simple process. Due to technical or other site-specific drilling constraints, usually several ice cores had to be recovered to reach the basis of the glacier at many drilling sites. For the EPICA Dome $\mathrm{C}$ project, only two long ice cores were drilled (see Fig. 1). The first one commenced during the 1996/1997 season (EDC96) and reached $\sim 790 \mathrm{~m}$ where the drilling system got stuck, while the second one started during the 1999/2000 (EDC99, only around $10 \mathrm{~m}$ from EDC96 at surface, this distance varying in depth due to different hole inclinations) season and stopped near the bedrock, at $\sim 3260 \mathrm{~m}$ depth. During the 1998/1999 season at EDC, a shallow hole named FIRETRACC was drilled

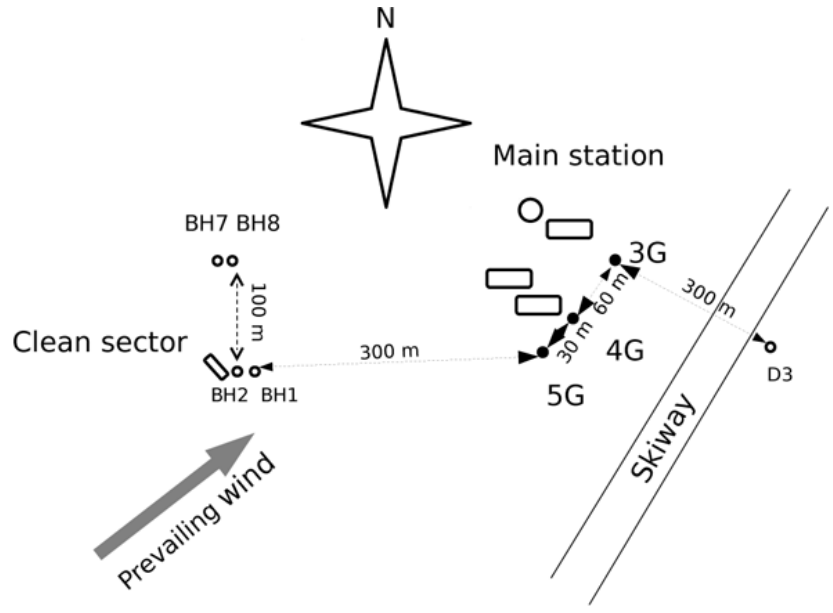

Fig. 2. Map illustrating the location of the camp facilities as well as the different boreholes considered in this study at Vostok station.

$200 \mathrm{~m} \mathrm{SW}$ of the deep drill site for sampling firn air, providing an extra ice core to a depth of $120 \mathrm{~m}$. For Vostok, several cores have been drilled since the initiation of the project in 1975 (see Vasiliev et al., 2007, for a review). For the present study (Figs. 2 and 3), we used the isotope profile from VK3G core (started in 1980 and reached $2083 \mathrm{~m}$ ), which represents the first Antarctic climatic record covering the last glacial cycle (Lorius et al., 1985). The record was supplemented for the upper part by the isotope record from VK-4G (started in 1983 and reached $2546 \mathrm{~m}$ depth). The continuous ECM record was performed on VK-5G (started in 1990 and reached $2503 \mathrm{~m}$ depth), and the record was complemented for the upper part by a couple of shallow cores from an electromechanical drill (VK-BH8 and VK-BH7 drilled during the 1995-1996 field season).

Some ice core synchronisation efforts have relied on matching of similar features in the isotope profiles (Parrenin et al., 2007b). This approach relies on the validity of two hypotheses: first, that the temperature is similar for sites from a given ice sheet with presumably similar climatic conditions, e.g. over the east Antarctic Plateau (Watanabe et al., 2003); and second, the stability of the isotope temperature relationship. While climate models and meteorological observations and reanalyses confirm a coherency of inter-annual to decadal temperature fluctuations on the east Antarctic Plateau (Masson-Delmotte et al., 2011), the intermittency of precipitation (Sime et al., 2009; Stenni et al., 2010; Laepple et al., 2011) and the local elevation changes (MassonDelmotte et al., 2011; Siddall et al., 2012) may induce sitespecific isotopic signals. Superimposed on this depositional variability, post-depositional processes linked to wind erosion and depth propagation of surface height variability are known to induce noise in isotopic profiles, even at the local scale (Ekaykin et al., 2002). Finally, uncertainties in ice core isotopic synchronisation arise from different sampling 


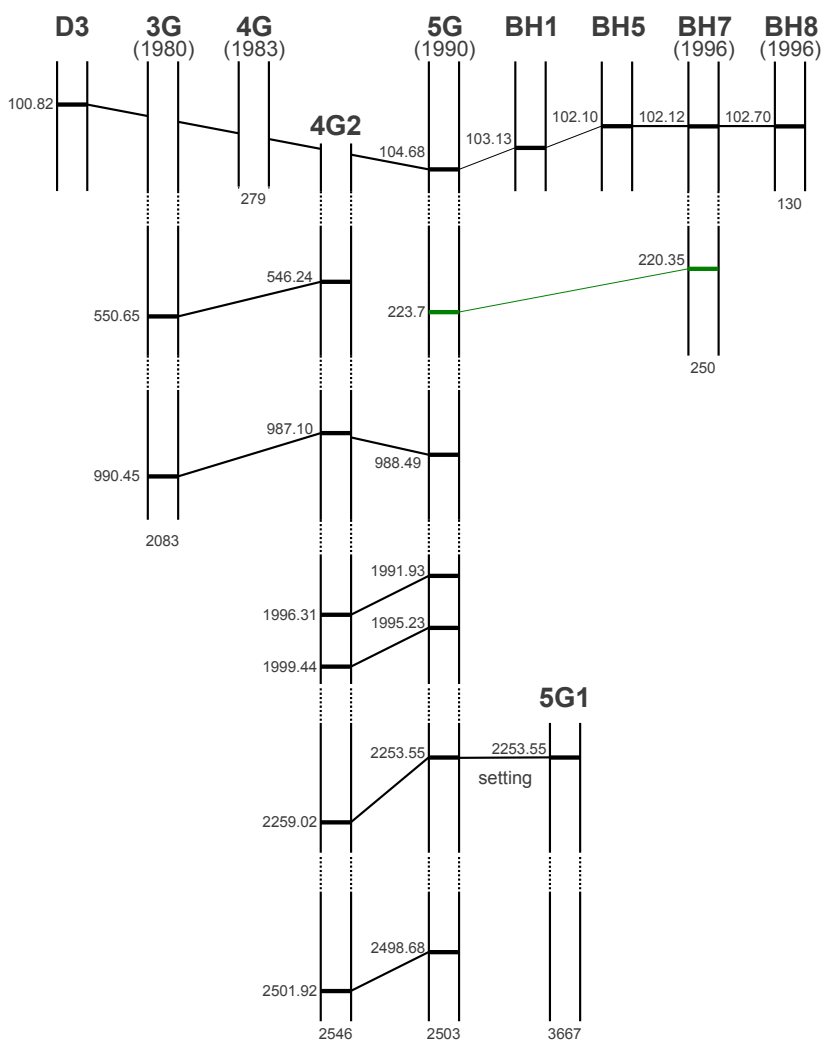

Fig. 3. Scheme of the different Vostok cores and shifts between them based on tephra recognition (black) and ECM synchronisation (green) (adapted from Basile, 1997).

resolutions. As an example of ice core synchronisation, the EDC3 age scale was transferred to the Vostok and Dome Fuji ice cores by synchronisation of the isotopic content of ice (Parrenin et al., 2007b). It is therefore important to test whether the hypothesis of in-phase isotopic variations for climatic transitions or millennial-scale events is valid at regional to continental scale. Testing isotopic synchronisation therefore requires using synchronisation methods independent of stable isotope records.

Volcanic signatures have this potential and also offer sharp stratigraphic markers: the deposition typically spans $1-2 \mathrm{yr}$, even for stratospheric events (Gao et al., 2006), which gives excellent accuracy to the synchronisation. Volcanic products (mainly minerals, glass particles and $\mathrm{SO}_{2}$, rapidly oxidised to $\mathrm{H}_{2} \mathrm{SO}_{4}$ ) are emitted into the stratosphere and/or into the high troposphere during volcanic eruptions, deposited on the Earth's surface via wet and/or dry deposition and preserved in ice or sediment sequences as tephra layers and/or sulfate (and as a consequence acidity and conductivity) spikes (Gao et al., 2008). Uncertainties in the matching of volcanic signatures arise from the fact that the distribution of volcanic aerosol particles in snow (e.g. non-sea salt sulphate) and tephra can be affected by atmospheric transport and postdepositional processes and therefore may not be detected or
Table 1. List of volcanic tie points between the EDC96 and EDC99 ice cores using the DEP records.

\begin{tabular}{rr}
\hline EDC96 & EDC99 \\
depth $(\mathrm{m})$ & depth $(\mathrm{m})$ \\
\hline 12.31 & 12.13 \\
29.73 & 29.60 \\
38.11 & 37.93 \\
39.24 & 39.07 \\
40.78 & 40.56 \\
41.50 & 41.22 \\
49.88 & 49.72 \\
60.35 & 60.21 \\
97.14 & 96.86 \\
100.01 & 99.76 \\
119.79 & 119.51 \\
125.27 & 125.03 \\
130.79 & 130.55 \\
133.81 & 133.58 \\
135.59 & 135.38 \\
140.29 & 140.04 \\
141.57 & 141.31 \\
144.97 & 144.70 \\
155.25 & 154.98 \\
160.17 & 159.98 \\
163.19 & 163.00 \\
169.43 & 169.28 \\
176.13 & 175.90 \\
186.12 & 185.84 \\
190.30 & 190.10 \\
208.73 & 208.56 \\
209.89 & 209.72 \\
214.07 & 213.84 \\
215.98 & 215.79 \\
232.75 & 232.57 \\
234.47 & 234.29 \\
238.98 & 238.80 \\
243.34 & 243.14 \\
249.31 & 249.12 \\
251.43 & 251.25 \\
259.47 & 259.34 \\
263.19 & 263.01 \\
264.15 & 264.02 \\
270.57 & 270.40 \\
277.13 & 277.00 \\
283.21 & 283.06 \\
302.52 & 302.38 \\
304.41 & 304.30 \\
305.67 & 305.55 \\
308.69 & 308.50 \\
311.10 & 310.96 \\
322.06 & 312.77 \\
338.32 .67 & 321.96 \\
\hline & 338.55 \\
\hline
\end{tabular}


Table 1. Continued.

\begin{tabular}{|c|c|}
\hline $\begin{array}{r}\text { EDC96 } \\
\text { depth }(m)\end{array}$ & $\begin{array}{r}\text { EDC99 } \\
\text { depth }(m)\end{array}$ \\
\hline 342.82 & 342.69 \\
\hline 343.73 & 343.60 \\
\hline 344.55 & 344.45 \\
\hline 353.03 & 352.84 \\
\hline 387.41 & 387.28 \\
\hline 389.47 & 389.34 \\
\hline 393.14 & 392.99 \\
\hline 398.02 & 397.80 \\
\hline 400.33 & 400.28 \\
\hline 404.28 & 404.12 \\
\hline 428.03 & 427.85 \\
\hline 428.32 & 428.17 \\
\hline 429.35 & 429.15 \\
\hline 432.21 & 431.96 \\
\hline 438.28 & 438.07 \\
\hline 451.73 & 451.52 \\
\hline 454.22 & 454.00 \\
\hline 471.17 & 470.95 \\
\hline 471.49 & 471.28 \\
\hline 472.27 & 472.06 \\
\hline 481.75 & 481.50 \\
\hline 494.87 & 494.66 \\
\hline 517.81 & 517.58 \\
\hline 564.63 & 564.40 \\
\hline 576.39 & 576.10 \\
\hline 579.21 & 578.94 \\
\hline 587.83 & 587.57 \\
\hline 593.71 & 593.48 \\
\hline 595.13 & 594.98 \\
\hline 626.93 & 626.54 \\
\hline 632.73 & 632.26 \\
\hline 636.82 & 636.42 \\
\hline 645.66 & 645.23 \\
\hline 662.31 & 661.85 \\
\hline 677.69 & 677.17 \\
\hline 691.69 & 691.14 \\
\hline 693.29 & 692.82 \\
\hline 699.29 & 698.68 \\
\hline 699.59 & 699.04 \\
\hline 701.12 & 700.63 \\
\hline 701.77 & 701.28 \\
\hline 703.11 & 702.58 \\
\hline 704.73 & 704.16 \\
\hline 710.57 & 710.00 \\
\hline 724.45 & 723.85 \\
\hline 726.91 & 726.32 \\
\hline 738.23 & 737.50 \\
\hline 739.81 & 739.14 \\
\hline 751.05 & 750.37 \\
\hline 762.93 & 762.24 \\
\hline 765.55 & 764.96 \\
\hline 775.73 & 775.04 \\
\hline 778.33 & 777.64 \\
\hline
\end{tabular}

Table 2. List of volcanic tie points between the VK-BH7 and VK$5 \mathrm{G}$ ice cores using the ECM records.

\begin{tabular}{rr}
\hline $\begin{array}{r}\text { VK-BH7 } \\
\text { depth }(\mathrm{m})\end{array}$ & $\begin{array}{r}\text { VK-5G } \\
\text { depth }(\mathrm{m})\end{array}$ \\
\hline 102.12 & 104.68 \\
212.76 & 216.01 \\
218.38 & 221.77 \\
220.35 & 223.70 \\
225.20 & 228.59 \\
233.33 & 236.76 \\
233.95 & 237.30 \\
\hline
\end{tabular}

detected with varying levels in Antarctic ice cores (Gao et al., 2008). Ice cores from the same ice sheet are presumed to record more similar volcanic signatures (both global and regional), even if some local events of very low intensity could be recorded only at local scale (Rasmussen et al., 2008). The total volcanic deposition can greatly differ spatially depending on geographic location, atmospheric transport pathways and the ratio between wet and dry deposition contributions (Castellano et al., 2005; Wolff et al., 2005; Gao et al., 2006).

The Toba super-eruption $\sim 73 \mathrm{kyr}$ ago is one of the most important of the last million years (e.g. Petraglia et al., 2007), with regional consequences such as climate cooling and deforestation in South Asia (Williams et al., 2009; Williams, 2011), though the global environmental impact of this eruption is debated (Robock et al., 2009). Indeed, some of the environmental changes occurring after the Toba event may have been caused by the strong concurrent millennial-scale climate variability, the Toba super-eruption reportedly being coincident with the end of Greenland Interstadial (GI) 20 (Zielinski et al., 1996). Chemical information from this large eruptive event should be recorded in ice sheets from both hemispheres. A possible candidate (a six-year-long sulfate spike exceptional in amplitude) has been proposed in the GISP2 ice core from Greenland (Zielinski et al., 1996), but none has so far been identified in Antarctic ice cores.

In this paper, we describe the stratigraphic correlation between the EPICA Dome C ice cores (EDC96 and EDC99) and the Vostok ice cores (BH7, 3G, 5G) records by using volcanic markers during the period 0-145 kyr BP. Previous studies compared Vostok and EDC96 electrical conductivity measurements (ECM) profiles for the last $10 \mathrm{kyr}$ (Wolff et al., 1999) and sulphate and ECM volcanic signatures in the EDC96 ice core back to $45 \mathrm{kyr}$ BP (Udisti et al., 2000, 2004). Here we extend the comparison over the last $145 \mathrm{kyr}$ and synchronize the ice core depth scales independently from any dating model. We discuss possible leads/lags of the EDC isotopic record relative to the Vostok one, analyse the Vostokdepth/EDC-depth isochronal diagram resulting from the volcanic synchronisation, and finally analyse the possible fingerprint of the Toba super-eruption in the Vostok and EDC ice cores. 

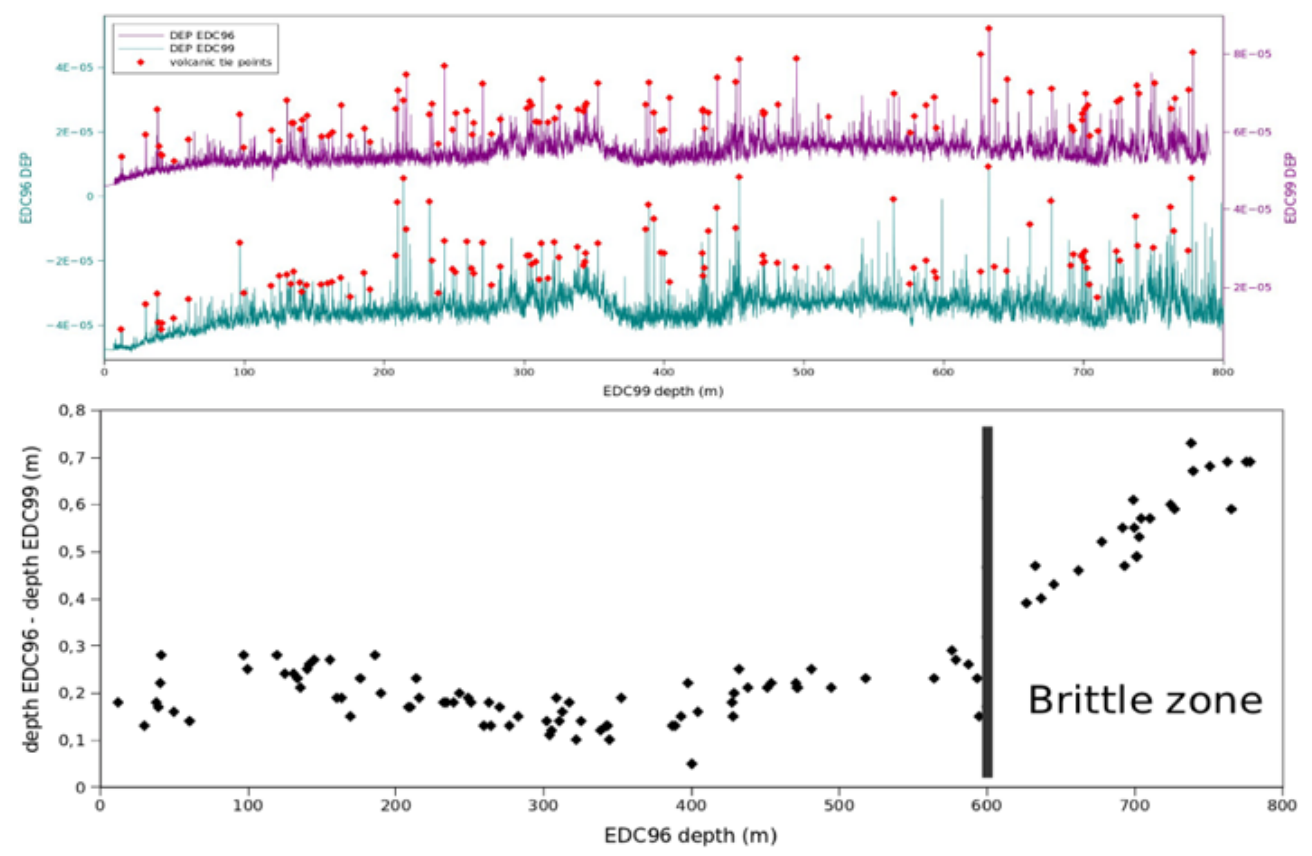

Fig. 4. Volcanic synchronisation of the EDC96 and EDC99 ice cores using the DEP records. (A) DEP records and volcanic tie points. (B) Resulting depth offset between EDC96 and EDC99. The vertical bar marks the start of the brittle zone.

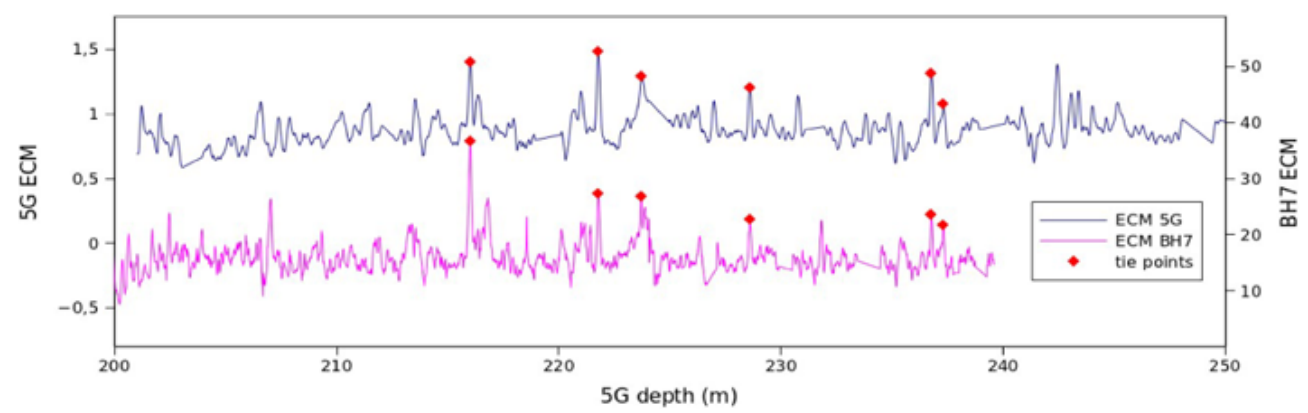

Fig. 5. Volcanic synchronisation of the VK-BH7 and VK-5G ice cores using the ECM records.

\section{Methods}

\subsection{The data}

\subsubsection{Depth measurements}

The depth of an ice core is either measured from the drilling cable length or from the logging of the ice cores, the latter being more widely used. In case of broken ice cores, the logging depth uncertainty is increased. This is particularly problematic in the depth zone corresponding to the transition between air bubbles and clathrates, where the ice is particularly brittle due to post drilling pressure relaxation ("brittle zone"). This brittle effect is present in the depth interval from $600-1200 \mathrm{~m}$ at EDC and $300-720 \mathrm{~m}$ at Vostok. For the Vostok ice core, the use of a thermal drill reduces the ice core quality as a result of added thermal stress and it extends the depth of fractured ice cores down to $\sim 850 \mathrm{~m}$.
It is absolutely essential that all analyses made on an ice core are put on the same reference depth scale. Only the logging depth can provide such a scale, because drilling depth is not consistent from run to run due to errors from the encoder wheel and varying dynamic tension in the drill cable. To put the records directly on an age scale is also not feasible, because chronologies are not absolute and will be improved in the course of time. A drawback of the logging depth is its offset to the true depth, which is used in glaciological models. This offset is due to the following reasons: (1) the hole is generally inclined and the core therefore longer than the vertical distance to the surface. (2) The core expands by elastic and plastic relaxation before logging. (3) The temperature of the core when logged is different from the in situ temperature. (4) The logging gauge is often calibrated at $+20^{\circ} \mathrm{C}$ but used at negative temperatures. (5) There are errors from marking and fitting the cores between runs and fitting broken cores 
(especially in the brittle zone). Offsets (1) to (4) can sum up to several meters for a deep drilling and could mostly be corrected for, but to our knowledge it has never been applied.

\subsubsection{ECM data}

The Vostok ECM data were acquired during several successive field seasons (from 1992 to 1998) as drilling operations advanced. The ECM system developed at Laboratoire de Glaciologie et Géophysique de l'Environnement (LGGE) was set up in the glaciological laboratory building near the ice core storage and facilities on the site. After one overnight preheating at $-15^{\circ} \mathrm{C}$ in a forced ventilated and insulated buffer, the full ice sections ( $1 \mathrm{~m}$ long, $10 \mathrm{~cm}$ diameter) were set on a tray on the bench, and a first $1 \mathrm{~cm}$ slice was cut by using a horizontal saw. ECM measurements were made using two electrodes $\left(1 \mathrm{~mm}^{2}\right.$ section in contact with ice separated by $20 \mathrm{~mm}$ distance) with a $1500 \mathrm{~V}$ potential difference. The electrodes were moved over the fresh ice surface at a speed of $2 \mathrm{~m} \mathrm{~min}^{-1}$, and the ECM signal was recorded by both digital and paper recorder systems. In order to test the stability of the measurement chain and the signal consistency between the different seasons, we used a 100 Mohm resistor (daily test) and repeated ECM measurement on selected ice cores that were kept stored at $-50^{\circ} \mathrm{C}$ (each season). The firn part of the upper VK-5G core was percolated by the water produced by the thermal drill, disturbing the ECM signal, which cannot be used. We therefore relied instead on the ECM record from two adjacent (4 $\mathrm{m}$ apart) deep electromechanically drilled cores (VK-BH8 down to $130 \mathrm{~m}$ and VK-BH7 down to $250 \mathrm{~m}$ respectively, drilled $400 \mathrm{~m}$ away from $\mathrm{VK}-5 \mathrm{G})$. The composite ECM signal is from VK-BH8 from $6 \mathrm{~m}$ down to $130 \mathrm{~m}$ depth; from VK-BH7, from $130 \mathrm{~m}$ to $230 \mathrm{~m}$; then from VK$5 \mathrm{G}$, below $230 \mathrm{~m}$ depth. Using the common volcanic events, depths from VK-BH8 and VK-BH7 were transferred to the VK-5G depth (logging depth), the latter taken as reference. Aberrant events corresponding to ice core breaks were removed. The data were then re-sampled every centimeter. The Vostok ECM data will be made available on the NOAA facility website (http://www.ncdc.noaa.gov/paleo/icecore/).

At Dome C, a new system, developed at the University of Bern, was used. A flat surface was prepared along the $2.2 \mathrm{~m}$ length of a core using a horizontal bandsaw and a milling device. The electrodes assembly consisted of seven electrodes at a spacing of $8 \mathrm{~mm}$ across the core. The electrodes were made of a carbon-doped silicon rubber. They were lowered onto the surface of the core, and $350 \mathrm{~V}$ was applied across each adjacent pair of electrodes in turn. The current between them was sampled at regular intervals after a settling time, and averaged. The electrodes were lifted and moved $1 \mathrm{~mm}$ along the core before the sequence was repeated. This procedure yielded six sets of data at $1 \mathrm{~mm}$ resolution. The data presented here are given as conductances averaged to $10 \mathrm{~mm}$ and corrected to $-15^{\circ} \mathrm{C}$. Documented major core breaks and ends have been removed from the ECM record. The FIRE-
Table 3. List of volcanic tie points between the Vostok BH7 and EDC99 ice cores. The equivalent Vostok 5G depths are given for convenience, following the $\mathrm{BH} 7-5 \mathrm{G}$ synchronisation discussed in the text.

\begin{tabular}{ccc}
\hline $\begin{array}{c}\text { VK-BH7 } \\
\text { depth }(\mathrm{m})\end{array}$ & $\begin{array}{c}\text { Equiv.VK-5G } \\
\text { depth }(\mathrm{m})\end{array}$ & $\begin{array}{c}\text { EDC99 } \\
\text { depth }(\mathrm{m})\end{array}$ \\
\hline 9.77 & 10.01 & 12.59 \\
22.99 & 23.57 & 29.60 \\
29.47 & 30.21 & 37.93 \\
75.08 & 76.96 & 96.86 \\
176.65 & 179.67 & 232.57 \\
184.24 & 187.31 & 243.13 \\
\hline
\end{tabular}

TRACC core was used for the top $100 \mathrm{~m}$, because measurements were not possible on the EDC96 and EDC99 ice cores due to logistic constraints.

\subsubsection{DEP data}

DEP data were obtained every $2 \mathrm{~cm}$ along the entire length of both the EDC96 and EDC99 cores. From the measured properties, a $100 \mathrm{kHz}$ conductivity was derived at each depth step (Wolff et al., 1999). Whereas ECM is believed to respond only to acidity, DEP conductivity responds to a wider range of impurities. However, under the conditions at Dome C, the signal is also almost always dominated by the acidity of the ice (Wolff, 2000). The Dome C DEP data will be made available on the NOAA facility website (http://www.ncdc.noaa. gov/paleo/icecore/).

\subsubsection{Sulfate data}

EDC96 sulphate analysis was performed in the field by fast ion chromatography (FIC), obtained by coupling an ionchromatographic (IC) system with a continuous flow analysis apparatus (Udisti et al., 2000). The system allowed 1 measurement per minute. Since the melting rate was kept constant at $4 \mathrm{~cm} \mathrm{~min}^{-1}$, a resolution of $4 \mathrm{~cm}$ (ice equivalent) was obtained. During the EDC99 processing, two IC systems worked in a parallel way ( $30 \mathrm{~s}$ shifted) and the resolution was increased to $2 \mathrm{~cm}$.

\subsubsection{Stable isotope data}

Both the deuterium $(\delta \mathrm{D})$ and the oxygen-18 $\left(\delta^{18} \mathrm{O}\right)$ contents of the ice are commonly used to get information on past temperature changes in polar regions. Hereafter, we will use the $\delta \mathrm{D}$ profiles, which were obtained at Laboratoire des Sciences du Climat et de l'Environnement (LSCE), both for the Vostok (Jouzel et al., 1987) and EDC cores (Jouzel et al., 2001, 2007; EPICA Community Members, 2004). The measurements were conducted on samples extracted from a band along the ice cores. The same uranium reduction technique was used for all these measurements performed on in-house 
built mass spectrometers (Hagemann and Lohez, 1978) with modifications being limited to the automatic injection device (Vaughn et al., 1998). All along the measurement period, the same protocol - consisting of four injections for a given water sample with at least two independent measurements for each - has been followed allowing to reach a precision of $\pm 0.5 \%$ o $(1 \sigma)$.

As fully described in Lorius et al. (1985) and Jouzel et al. (2007), the published Vostok $\delta \mathrm{D}$ record was obtained from the VK-3G $2083 \mathrm{~m}$ deep ice core below $138 \mathrm{~m}$ with a complementary dataset obtained on the adjacent VK-4G $279 \mathrm{~m}$ core. The sampling was conducted at low resolution with, for example, 1.5 to $2 \mathrm{~m}$ samples below $1400 \mathrm{~m}$ and a total ice recovery of $85 \%$ and some missing samples (sampling was particularly difficult in the 300 to $800 \mathrm{~m}$ range with missing samples at depth intervals of up to $8 \mathrm{~m}$ ). Additional measurements have been more recently obtained on VK-4G and VK-5G (Petit et al., 1999 and unpublished data). The EDC $\delta \mathrm{D}$ published profile was obtained with a higher $55 \mathrm{~cm}$ depth resolution on a continuous basis in combining measurements performed on EDC96 down to $788 \mathrm{~m}$ and on EDC99 below (Jouzel et al., 2007).

\subsection{Synchronisation method}

\subsubsection{EDC96-EDC99 volcanic synchronisation}

The DEP records have been used to synchronize the EDC96 and EDC99 ice cores down to $790 \mathrm{~m} .104$ prominent pairs of spikes corresponding to volcanic events have been used to determine common age horizons (see Table 1 and Fig. 4a).

The depth difference (see Fig. $4 \mathrm{~b}$ ) ranges from $\sim 0.05 \mathrm{~m}$ to $\sim 0.75 \mathrm{~m}$, EDC96 recording similar events at slightly deeper depths compared to EDC99. The depth difference remains largely confined between 0.1 and $0.3 \mathrm{~m}$ down to $600 \mathrm{~m}$. The small oscillations in this depth interval are probably due to spatial irregularities of snow deposition/re-deposition (sastrugi, Ekaykin et al., 2002; Barnes et al., 2006); the logging uncertainty could indeed only contribute a systematic error of order $<1 \mathrm{~mm}$ per $2.2 \mathrm{~m}$. Between 600 and $790 \mathrm{~m}$, the depth difference increases to $\sim 0.7 \mathrm{~m}$, probably due to logging differences between the two cores. Indeed, the $600 \mathrm{~m}$ depth corresponds to the start of the brittle zone at EDC.

We use this EDC96/EDC99 synchronisation to anchor the EDC96 records on EDC99 depths. We assume that (1) the offset is $0.18 \mathrm{~m}$ at surface (this value corresponds to the shallower data point in Table 1 and Fig. 4); (2) the offset varies linearly between the volcanic tie points.

\subsubsection{Vostok BH7-5G volcanic synchronisation}

The ECM records have been used to synchronize the $\mathrm{BH} 7$ and $5 \mathrm{G}$ ice cores in the depth interval where the records overlap, i.e. between 200 and $240 \mathrm{~m}$. Six pairs of spikes corresponding to volcanic events have been recognized in this
Table 4. List of volcanic tie points between the EPICA Dome C EDC99 and Vostok 5G ice cores.

\begin{tabular}{|c|c|}
\hline $\begin{array}{r}\text { VK-5G } \\
\text { depth }(m)\end{array}$ & $\begin{array}{r}\text { EDC99 } \\
\text { depth }(m)\end{array}$ \\
\hline 289.94 & 387.31 \\
\hline 291.41 & 389.32 \\
\hline 294.21 & 393.00 \\
\hline 302.92 & 404.14 \\
\hline 328.62 & 438.09 \\
\hline 372.65 & 492.53 \\
\hline 374.29 & 494.64 \\
\hline 422.85 & 553.12 \\
\hline 432.36 & 564.39 \\
\hline 496.49 & 632.23 \\
\hline 511.15 & 645.92 \\
\hline 547.33 & 677.14 \\
\hline 571.76 & 700.62 \\
\hline 657.45 & 790.52 \\
\hline 658.85 & 791.87 \\
\hline 665.45 & 798.49 \\
\hline 766.44 & 874.22 \\
\hline 947.52 & 1013.73 \\
\hline 955.56 & 1019.45 \\
\hline 983.8 & 1040.5 \\
\hline 1023.5 & 1071.2 \\
\hline 1035 & 1078.95 \\
\hline 1036 & 1079.7 \\
\hline 1038.45 & 1081.28 \\
\hline 1043.56 & 1084.73 \\
\hline 1048.35 & 1087.94 \\
\hline 1063 & 1097.96 \\
\hline 1063.96 & 1098.63 \\
\hline 1119.53 & 1140.58 \\
\hline 1156.55 & 1173.05 \\
\hline 1160.5 & 1176.13 \\
\hline 1164.35 & 1179 \\
\hline 1244.91 & 1238.72 \\
\hline 1283.45 & 1271.2 \\
\hline 1291.8 & 1278.6 \\
\hline 1332.6 & 1312.4 \\
\hline 1334.65 & 1314.15 \\
\hline 1337.6 & 1316.3 \\
\hline 1372.44 & 1342.72 \\
\hline 1374.64 & 1344.23 \\
\hline 1386.73 & 1353.24 \\
\hline 1465.02 & 1429.12 \\
\hline 1478.49 & 1439.88 \\
\hline 1483.12 & 1443.42 \\
\hline 1488.81 & 1447.72 \\
\hline 1489.7 & 1448.39 \\
\hline 1493.34 & 1451.03 \\
\hline 1495.23 & 1452.38 \\
\hline 1498.5 & 1454.69 \\
\hline 1500.34 & 1455.98 \\
\hline 1501.33 & 1456.59 \\
\hline
\end{tabular}


Table 4. Continued.

\begin{tabular}{|c|c|}
\hline $\begin{array}{r}\text { VK-5G } \\
\text { depth }(m)\end{array}$ & $\begin{array}{r}\text { EDC99 } \\
\text { depth }(m)\end{array}$ \\
\hline 1521.75 & 1470.51 \\
\hline 1537.39 & 1480.96 \\
\hline 1540.2 & 1482.8 \\
\hline 1550.39 & 1489.18 \\
\hline 1559.18 & 1494.9 \\
\hline 1571.15 & 1502.62 \\
\hline 1576.67 & 1506.28 \\
\hline 1582.09 & 1510.12 \\
\hline 1584 & 1511.51 \\
\hline 1618.24 & 1538.62 \\
\hline 1621.23 & 1541.13 \\
\hline 1637.66 & 1554.63 \\
\hline 1648.56 & 1563 \\
\hline 1662.08 & 1572.65 \\
\hline 1673.03 & 1580.3 \\
\hline 1673.74 & 1580.78 \\
\hline 1674.22 & 1581.11 \\
\hline 1682.91 & 1587.15 \\
\hline 1699.71 & 1598.85 \\
\hline 1707.25 & 1604.1 \\
\hline 1711.5 & 1607.2 \\
\hline 1715.55 & 1610.1 \\
\hline 1743.59 & 1631.16 \\
\hline 1801.7 & 1676 \\
\hline 1805.43 & 1678.9 \\
\hline 1811.99 & 1683.97 \\
\hline 1820.8 & 1690.85 \\
\hline 1828.3 & 1696.67 \\
\hline 1838.34 & 1704.3 \\
\hline 1844.6 & 1708.9 \\
\hline 1847.65 & 1711.1 \\
\hline 1855.5 & 1716.85 \\
\hline 1869.7 & 1726.85 \\
\hline 1876.63 & 1731.78 \\
\hline 1880.8 & 1734.65 \\
\hline 1896.85 & 1745.91 \\
\hline 1899.85 & 1748.07 \\
\hline 1926.7 & 1767.4 \\
\hline 1929 & 1769 \\
\hline 1932.75 & 1771.48 \\
\hline 1934.9 & 1772.9 \\
\hline 1948.7 & 1781.6 \\
\hline 1950.95 & 1782.85 \\
\hline 1962.65 & 1789.22 \\
\hline 1966.36 & 1791.25 \\
\hline 1982.11 & 1799.25 \\
\hline 1991.93 & 1804 \\
\hline
\end{tabular}

Table 5. Isotopic synchronization between VK and EDC99. VK depth is a combination of different logging depths (as defined in Petit et al., 1999).

\begin{tabular}{rr}
\hline VK & $\begin{array}{r}\text { EDC99 } \\
\text { depth (m) }\end{array}$ \\
\hline 262 & 360 \\
287 & 385 \\
311 & 418 \\
357 & 472 \\
449 & 587 \\
467 & 605 \\
490 & 623 \\
499 & 636 \\
514 & 650 \\
540 & 670 \\
570 & 700 \\
596 & 729 \\
608 & 740 \\
625 & 759 \\
664 & 800 \\
773 & 878 \\
800 & 899 \\
920 & 996 \\
981 & 1040 \\
1010 & 1061 \\
1062 & 1101 \\
1192 & 1200 \\
1256 & 1245 \\
1450 & 1412 \\
1484 & 1440 \\
1783 & 1657 \\
\hline & \\
& \\
& 69
\end{tabular}

interval and considered to represent common age horizons (see Table 2 and Fig. 5).

The depth difference ranges between 3.25 and $3.43 \mathrm{~m}, 5 \mathrm{G}$ being deeper than $\mathrm{BH} 7$ for the same horizon. This shift is significantly larger than the $2.56 \mathrm{~m}$ shift determined at $104.68 \mathrm{~m}$ (depth in 5G) with the help of a tephra horizon (see Fig. 3). We do not know at this stage if this increased offset is due to logging uncertainties or to a varying accumulation pattern.

We used this synchronisation to transfer the $\mathrm{BH} 7$ records on $5 \mathrm{G}$ depths. We assumed that (1) the offset is 0 at surface; (2) the offset varies linearly between the volcanic tie points (including the tephra horizon at $104.68 \mathrm{~m} \mathrm{5G} \mathrm{depth).}$

\subsubsection{EDC99/VK-5G and EDC99/VK-BH7 synchronisations}

An initial prior synchronization between Vostok and EDC was previously achieved using the deuterium records. One cannot assume perfect synchroneity of the isotope records, but this step allows positioning within a few meters. This synchronisation was later refined using the ECM record from the Vostok 5G and $\mathrm{BH} 7$ ice cores, the sulfate record from the EDC96 ice core and the ECM, DEP and sulfate records from 
A)

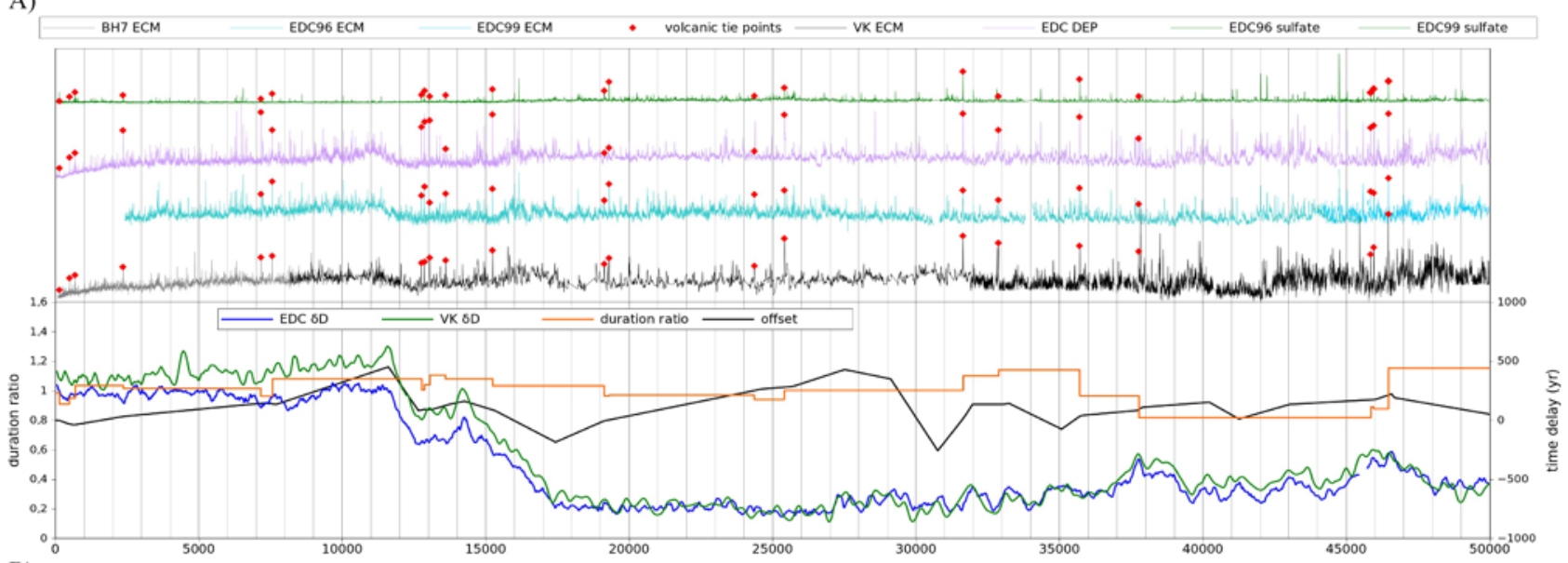

B)
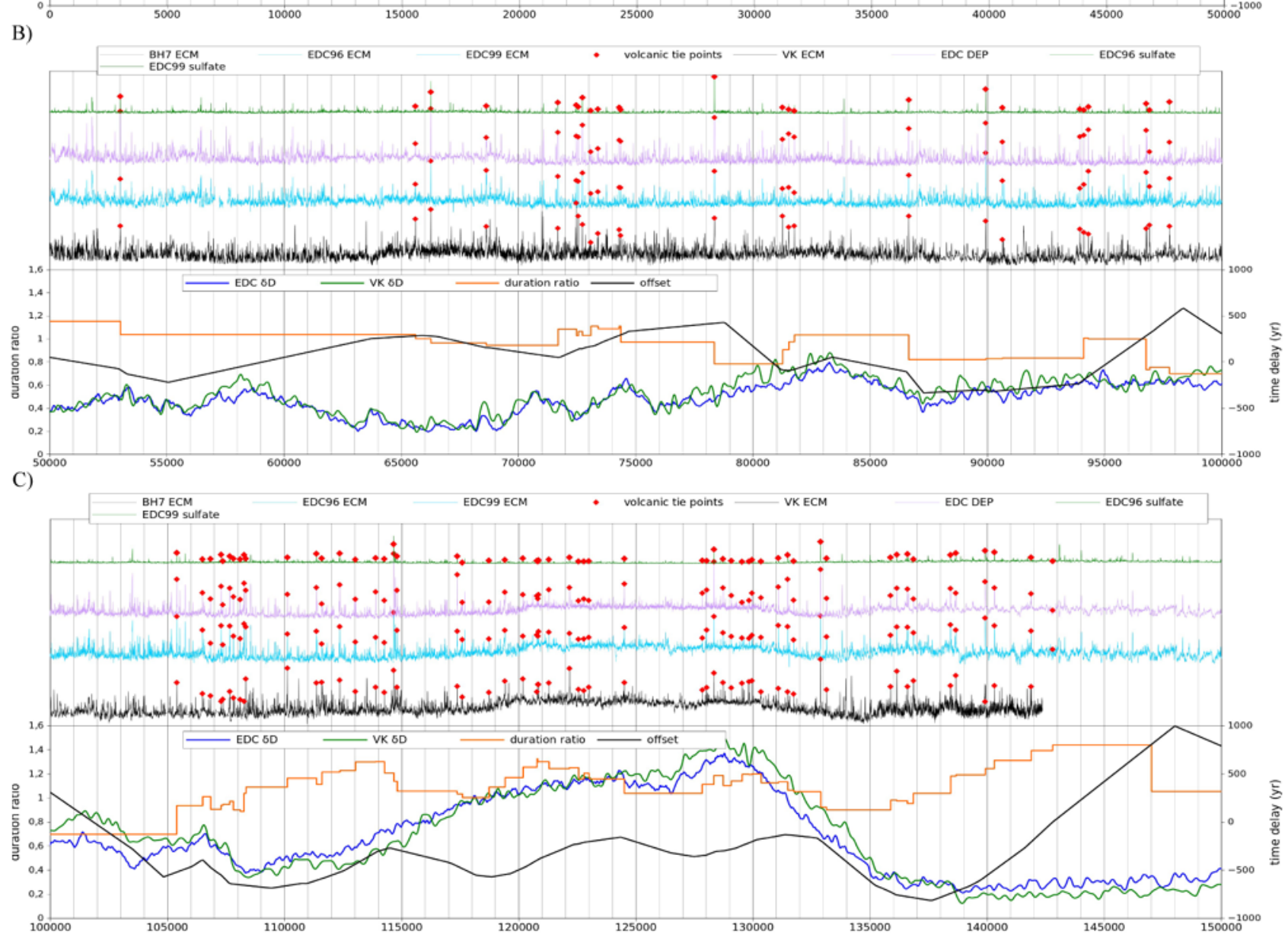

Fig. 6. EDC/VK volcanic synchronisation on the EDC3 age scale. (A) 0-50 kyr BP; (B) 50-100 kyr BP; (C) 100-150 kyr BP. For (A), (B), (C): Top) Black: ECM record from the VK-5G ice core. Grey: ECM record from the VK-BH7 ice core. Blue: ECM record from the EDC96 and EDC99 ice core. Purple: DEP record from the EDC99 ice core. Green: sulfate records from the EDC96 and EDC99 ice cores. Red diamonds: volcanic tie points. For simplicity, y-axes are not plotted. Bottom) Blue: Deuterium record from the EDC ice core. Green: Deuterium record from the Vostok ice core. The deuterium records have been resampled every $20 \mathrm{yr}$ and an 11-point moving average was applied. Orange: ratio of the duration between two tie points in VK-FGT1 (Parrenin et al., 2004) and EDC3 (Parrenin et al., 2007b). Black: time delay between the VK-3G and EDC deuterium records after volcanic synchronisation. For simplicity, y-axes for the deuterium records are not plotted. 
A)

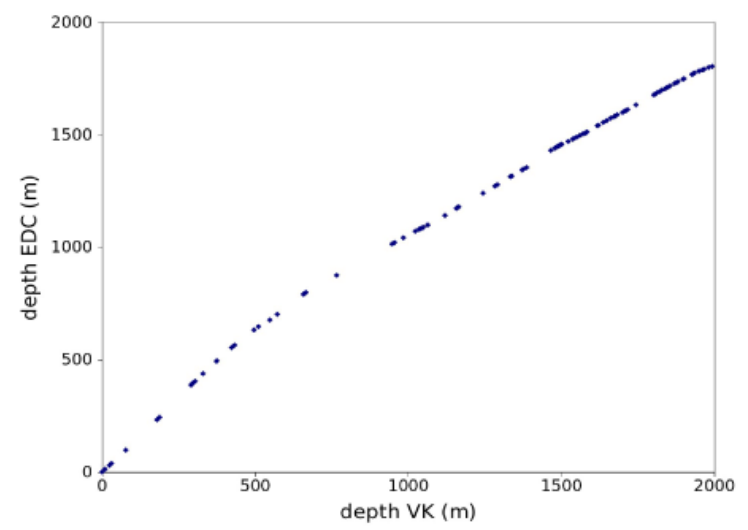

B)

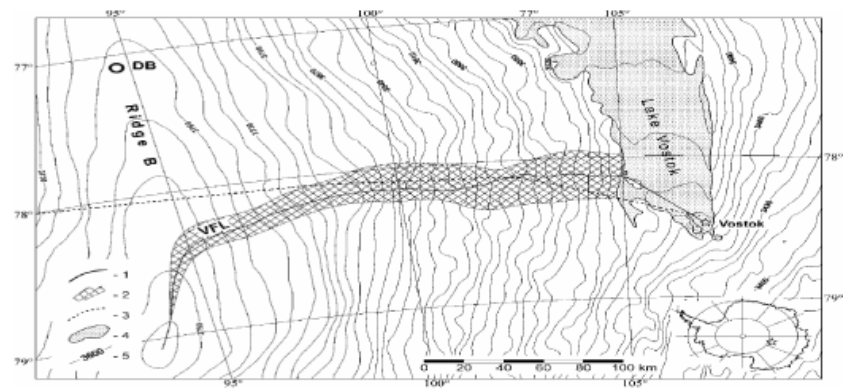

Fig. 7. (A) Volcanic tie points in a depth-VK/depth-EDC diagram. (B) The Vostok flow line (VFL) between Ridge B and Vostok, with the geographic situation of this Antarctic region in the lower right corner. Adapted from Salamatin et al. (2009a). The steep slope in graph (A) between 0 and $500 \mathrm{~m}$ in VK corresponds to the lake part of the flow line, where the accumulation and bedrock elevation are lower than upstream.

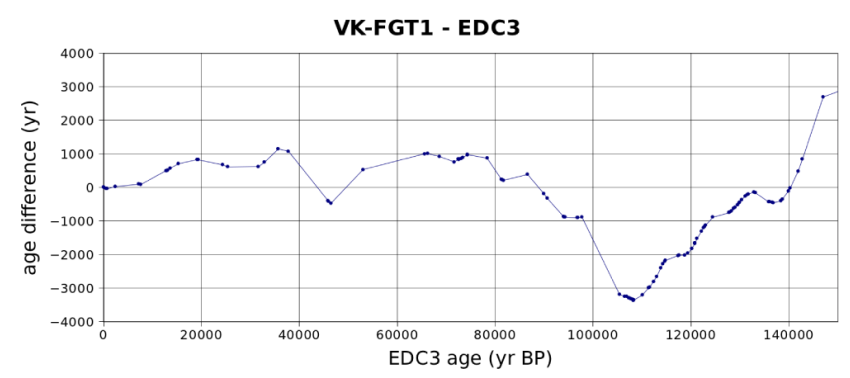

Fig. 8. Comparison of the VK-FGT1 and EDC3 time scales at the volcanic synchronisation tie points.

the EDC99 ice core. The EDC96 sulfate and ECM data were transferred to EDC99 depths using the volcanic synchronisation between EDC96 and EDC99, while the BH7 depths were transferred to $5 \mathrm{G}$ using the volcanic synchronisation as previously explained.

Three different teams conducted the volcanic synchronisation work (FP, EWW and SOR+BV), and one other team checked specific time periods (MS). We adopted only the tie points where there was a consensus. In total, 102 volcanic tie points were derived and are listed in Tables 3 and 4.

During the process of volcanic synchronisation, we use the pattern of peaks with age rather than just the height of peaks. As a next step, a series of the most obvious large peaks in each core is matched up, seeking a pattern of at least three peaks that have the same relative spacings in the two cores. Finally, the pattern of smaller peaks in between the clear matches is made, again seeking a close match in the relative spacings between peaks. The EWW and SOR+BMV teams used the relative depth spacing, while the FP team both used the relative spacing in depth and in age. For the later, prior glaciological age scales at EDC and VK were used: for EDC, the EDC3 age scale (Parrenin et al., 2007b) was used, while for Vostok the prior age scale is VK-FGT1 (Parrenin et al., 2004). In Fig. 6, the ratio of the duration of one time interval in the Vostok and EDC glaciological time scales is plotted. The FP team tried to keep this ratio as close as possible to 1 and as smooth as possible.

The synchronisation is convincing for the period 105$145 \mathrm{kyr} \mathrm{BP}$ but is more difficult for the period after $105 \mathrm{kyr}$ BP. For this last period, the synchronisation is thus only tentative.

For the period 0-45 kyr BP, we revisited the synchronisation by Udisti et al. (2004) and we in particular removed several tie points which were judged as too uncertain. Our approach is thus more conservative than the approach by Udisti et al. (2004).

\section{Discussion}

\subsection{Climatic implications: EDC-VK isotope phasing}

In the following we investigate the offset between EDC$(96,99)$ and VK-3G isotope records, taking into account the volcanic synchronisation that has been done using the VK-5G ice core. The resulting EDC-VK offset is plotted in Fig. 6. It has been computed as the difference between two EDC3-based Vostok chronologies: one based on volcanic synchronisation (Tables 3 and 4) and one using an isotopic synchronisation based on tie points where the isotopic slope changes abruptly (Table 5). This offset thus should be interpreted as (1) inaccuracy of the volcanic synchronization or (2) inaccuracy of the isotopic synchronization or (3) depth shift between the VK-5G ice core (where 


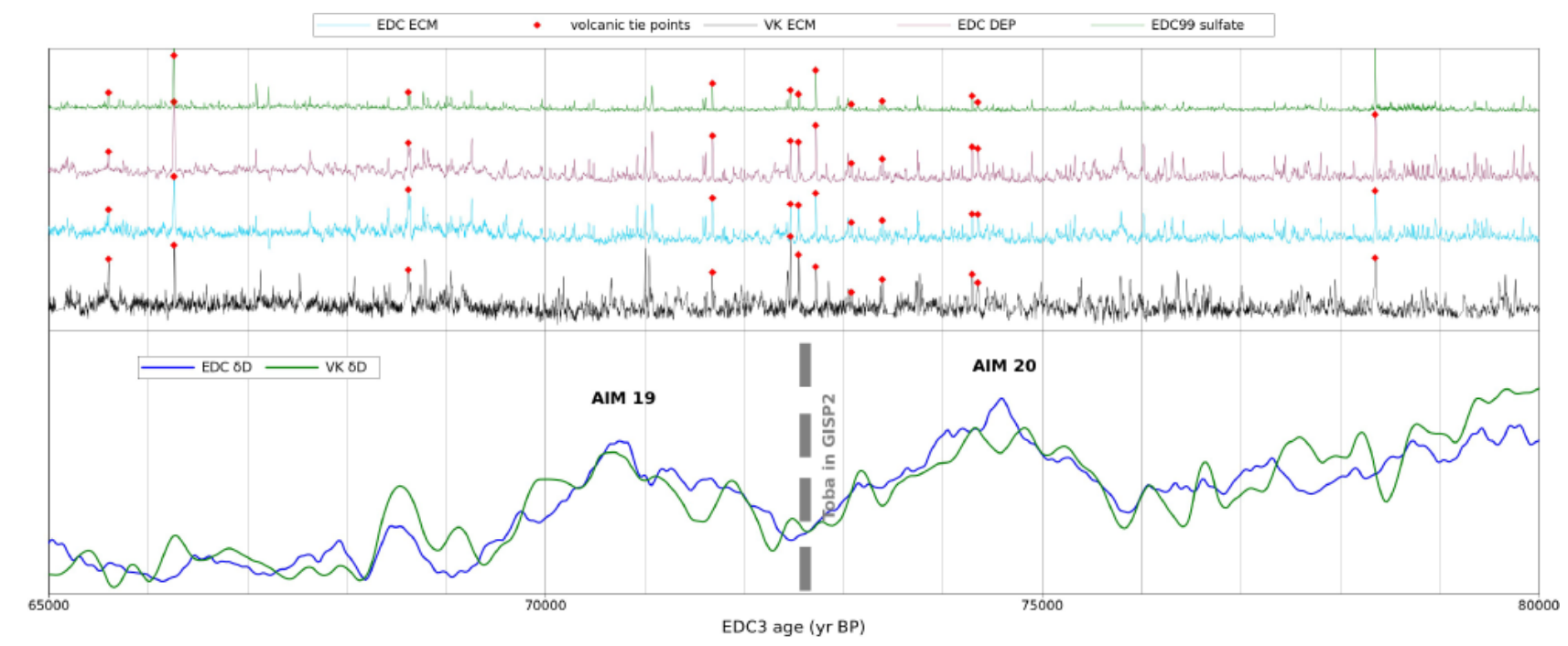

Fig. 9. Vostok - EDC synchronisation during the period 65-80 kyr BP, centered on the likely age of the Toba eruptive event. All records have been placed on the EDC3 age scale. (Top) Black: ECM record from the VK-5G ice core. Blue: ECM record from the EDC96 and EDC99 ice cores. Purple: DEP record from the EDC99 ice core. Green: sulfate records from the EDC96 and EDC99 ice cores. Red diamonds: volcanic tie points. For simplicity, the y-axes are not plotted. (Bottom) Blue: Deuterium record from the EDC ice core. Green: Deuterium record from the Vostok ice core. For simplicity, the y-axes are not plotted.

the volcanic synchronization is done) and VK-3G ice core (where the isotopic content was measured) or (4) real isotopic phasing between the VK and EDC sites.

A positive value of this offset means that the EDC isotopic record is younger with respect to the VK isotopic record. This offset rarely exceeds $\pm 500 \mathrm{yr}$. The volcanic synchronization is only virtually certain for the time interval 105 $145 \mathrm{kyr}$ BP. Unfortunately, during this period, only one isotopic tie point could be derived at $\sim 126.5 \mathrm{kyr}$ BP. The resulting offset for this period is $-320 \mathrm{yr}$. However, at $100 \mathrm{kyr} \mathrm{BP}$, $1 \mathrm{~m}$ of ice at Vostok typically represents $100 \mathrm{yr}$. This apparent offset could thus be due to a $\sim 3 \mathrm{~m}$ shift between the VK-3G and VK-5G ice cores (3G being deeper than $5 \mathrm{G}$ for the same age). Such a depth shift would not be surprising given the depth shifts observed based on tephra recognition (Fig. 3). We therefore do not observe any significant isotopic phasing between the EDC and VK sites, but new isotopic measurements on the VK-5G ice cores will allow us to look at this question in more detail.

\subsection{Glaciological implications}

The Vostok - EDC depth to depth relationship (Fig. 7) indicates a change to lower slope at around $500 \mathrm{~m}$ Vostok depth (corresponding to $\sim 32 \mathrm{kyr}$ on the EDC3 age scale), which persists throughout the ice representing the last interglacial period. This corresponds to thicker layers below $500 \mathrm{~m}$ depth than in younger ice for the Vostok record relative to EDC. There are two factors explaining these large annual layers at Vostok below $500 \mathrm{~m}$ depth. First, the thinning function increases between $400 \mathrm{~m}$ and $800 \mathrm{~m}$ at Vostok because of a higher bedrock upstream of the Vostok station (Parrenin et al., 2004). Second, along the flow line, the ice $500 \mathrm{~m}$ deep at Vostok originates $\sim 37-39 \mathrm{~km}$ upstream (Parrenin et al., 2004; Salamatin et al., 2009a), where the accumulation rate is $30 \%$ larger than for sites close to the station and over the Lake Vostok region, as reconstructed from isochrone layers (Salamatin et al., 2009a).

Parrenin et al. (2004) took into account these two parameters (higher accumulation rate and bedrock elevation upstream of Vostok station) when producing the modelled VKFGT1 time scale. We can now compare in detail this time scale with the EDC3 time scale for the EDC ice core using the volcanic synchronisation (see Fig. 8). We can note that the agreement is very good back to 100 kyr: the difference never exceeds $\sim 1 \mathrm{kyr}$, which means that spatial variations of accumulation rate and bedrock elevation alone can explain the change of slope at $\sim 500 \mathrm{~m}$ depth at Vostok.

Our interpretation of the change of slope in the EDCdepth/VK-depth diagram is different from the interpretation by Udisti et al. (2004) concentrating on the relative temporal variations of accumulation. We think that we have at this point no firm data to conclude that the temporal variations of accumulation were different at the two sites, even if this hypothesis cannot be completely dismissed.

The VK-FGT1 - EDC3 difference decreases to below $-3 \mathrm{kyr}$ in the $105-110 \mathrm{kyr}$ interval and increases again to $\sim 3 \mathrm{kyr}$ at $150 \mathrm{kyr}$ BP. It means that the time interval between 105 and $150 \mathrm{kyr}$ BP appears to be $6 \mathrm{kyr}$ longer in VK-FGT1 than in EDC3. The reconciliation between these two glaciological dating models requires further investigations. 


\subsection{The $\sim 73$ kyr BP Toba eruptive event}

Before searching for signs of the Toba in the Antarctic ice, it would be important to know if there were only one or several eruptive events from this volcano during this time period. Westgate et al. (1998) unequivocally demonstrated that all the presently known Toba tephra occurrences in Peninsular India belong to the $73 \mathrm{kyr}$ BP Toba super-eruption. There were however several known eruptions of this volcano during the Quaternary (see Westaway et al., 2011, for an exhaustive review).

Previous radiometric ages for the $\sim 73 \mathrm{kyr}$ BP Toba supereruption range from an isothermal plateau, fission track age of $68 \pm 7 \mathrm{kyr}$ on glass from a deposit in Malaysia (Chesner et al., 1991) to K-Ar ages of $75 \pm 12$ and $74 \pm 3 \mathrm{kyr}$ on tuff deposits (Ninkovitch et al., 1978) and an Ar-Ar age of $73 \pm 4 \mathrm{kyr}$ also on sanidine from the tuff (Chesner et al., 1991). This leaves a large number of candidates in the Antarctic ice: between 69 and $77 \mathrm{kyr}$ BP, there are about 10 relatively large spikes in the EDC and Vostok records (see Fig. 9), none being exceptional in terms of amplitude.

To refine the search for the Toba volcanic signature, we account for the fact that Zielinski et al. (1996) found a huge sulphate spike in GISP2 ice core, which they attributed to the Toba mega eruption at the end of GI-20. Following the classical seesaw hypothesis (Stocker and Johnsen, 2003), inspired by Blunier and Brook (2001) using the Byrd and GISP2 ice cores and refined using the NorthGRIP-EDML synchronisation (Capron et al., 2010), the end of a Greenland Interstadial (GI) is contemporaneous with the onset of an Antarctic warming. The end of GI-20 in the GISP2 should thus correspond to the trough between Antarctic Isotope Maximums (AIM) 19 and 20 in the Vostok and EPICA Dome $\mathrm{C}$ isotope records. During this time period in both Antarctic records, ECM records display three large spikes that may represent the corresponding counterpart of this event (see Fig. 9). These spikes are also present in the EDC, DEP and sulphate records. However, they are not significantly larger than many other peaks in the records.

\section{Conclusion and outlook}

102 volcanic tie points between EDC and Vostok are proposed in the $0-145 \mathrm{kyr} B \mathrm{P}$ time interval, updating and complementing the previous 56 tie points reported for the time interval $0-45 \mathrm{kyr}$ by Udisti et al. (2004). This new synchronisation will stand as a foundation for the establishment of the next synchronized Antarctic Ice Core Chronology 2012. The synchronization is robust for the last interglacial period (105-145 kyr) but is more difficult to constrain during the last glacial period and the Holocene. This synchronisation will be extended for older time periods and to other ice cores (Dome Fuji, WAIS, etc.) in further studies. No significant phase difference is detected between the EDC and Vostok isotopic records, but possible depth shifts between the Vostok $3 \mathrm{G}$ and $5 \mathrm{G}$ ice cores prevent from looking at this problem accurately. A change of slope in the VK-depth/EDC-depth diagram is explained by a larger surface accumulation rate upstream of Vostok as well as less thinned layers in depth at Vostok. Contrary to Udisti et al. (2004), we did not invoke any significant temporal relative change of accumulation between the Vostok and EDC sites, even if this later hypothesis cannot be dismissed. For the period $\sim 72.5 \mathrm{kyr} B \mathrm{~B}$, three major spikes on the volcanic records from the two Antarctic ice cores may correspond to a huge sulphate spike found in Greenland GISP2 and attributed to the Toba eruption event.

The search for glass shards for securely pinpointing the volcanic source is under consideration. Moreover, there is now a need to build an automatic and objective mathematical method to accomplish the volcanic synchronisation. This is a complex task, however, because it involves several nontrivial steps: (1) automatically selecting the volcanic spikes in the volcanic records (Gazeaux et al., 2012); (2) defining a likelihood function of a certain volcanic synchronisation based on the relative amplitude of the spikes and on the required distortions in the age scales; (3) finding the most probable synchronisation scenario with an optimization algorithm, which will have to deal with this highly non-linear problem. Such an automatic method has already been built (Barnes et al., 2006), but it was designed to synchronize two nearby ice cores, where not only the main conductivity spikes but also the conductivity background can be synchronised.

Acknowledgements. We thank M.-F. Loutre for helpful discussions and N. Dunbar and an anonymous reviewers for their careful reviews. We wish to also thank all participants to the field seasons at Vostok and at Dome C. This work is a contribution to the European Project for Ice Coring in Antarctica (EPICA), a joint European Science Foundation/European Commission scientific program, funded by the EU and by national contributions from Belgium, Denmark, France, Germany, Italy, The Netherlands, Norway, Sweden, Switzerland and the United Kingdom. The main logistic support was provided by IPEV and PNRA (at Dome C), (at Dronning Maud Land) and Russian Antarctic Expeditions (RAE at Vostok). This is EPICA publication no. 279.

Edited by: E. Brook

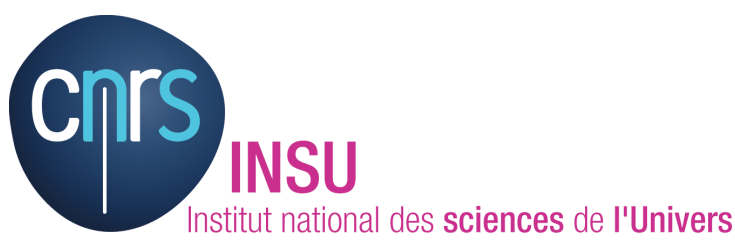

The publication of this article is financed by CNRS-INSU. 


\section{References}

Barnes, P. R. F., Wolff, E. W., and Mulvaney, R.: A 44 kyr paleoroughness record of the Antarctic surface, J. Geophys. Res., 111, D03102, doi:10.1029/2005JD006349, 2006.

Basile, I.: Origine des aérosols volcaniques de la carotte de glace de Vostok (Antarctique), PhD thesis, Univ. Joseph Fourier, 1997.

Blunier, T. and Brook, E. J.: Timing of millennial-scale climate change in Antarctica and Greenland during the last glacial period, Science, 291, 109-112, 2001.

Capron, E., Landais, A., Chappellaz, J., Schilt, A., Buiron, D., Dahl-Jensen, D., Johnsen, S. J., Jouzel, J., Lemieux-Dudon, B., Loulergue, L., Leuenberger, M., Masson-Delmotte, V., Meyer, H., Oerter, H., and Stenni, B.: Millennial and sub-millennial scale climatic variations recorded in polar ice cores over the last glacial period, Clim. Past, 6, 345-365, doi:10.5194/cp-6-3452010, 2010.

Castellano, E., Becagli, S., Hansson, M., Hutterli, M., Petit, J. R., Rampino, M. R., Severi, M., Steffensen, J. P., Traversi, R., and Udisti, R.: Holocene volcanic history as recorded in the sulfate stratigraphy of the European Project for Ice Coring in Antarctica Dome C (EDC96) ice core, J. Geophys. Res., 116, D06114, doi:10.1029/2004JD005259, 2005.

Chesner, C. A., Rose, W. I., Deino, A., Drake, R., and Westgate, J. A.: Eruptive history of Earths larget Quaternary caldera (Toba, Indonesia) clarified, Geology, 19, 200-203, 1991.

Dreyfus, G. B., Parrenin, F., Lemieux-Dudon, B., Durand, G., Masson-Delmotte, V., Jouzel, J., Barnola, J.-M., Panno, L., Spahni, R., Tisserand, A., Siegenthaler, U., and Leuenberger, M.: Anomalous flow below $2700 \mathrm{~m}$ in the EPICA Dome $\mathrm{C}$ ice core detected using $\delta^{18} \mathrm{O}$ of atmospheric oxygen measurements, Clim. Past, 3, 341-353, doi:10.5194/cp-3-341-2007, 2007.

Ekaykin, A. A., Lipenkov, V. Y., Barkov, N. I., Petit, J.-R., and Masson-Delmotte, V.: Spatial and temporal variability in isotope composition of recent snow in the vicinity of Vostok station, Antarctica: implications for ice-core record interpretation, Ann. Glaciol., 35, 181-186, 2002.

Augustin, L., Barbante, C., Barnes, P. R. F., Barnola, J. M., Bigler, M., Castellano, E., Cattani, O., Chappellaz, J., Dahl-Jensen, D., Delmonte,B., Dreyfus, G., Durand, G., Falourd, S., Fischer, H., Fluckiger, J., Hansson, M. E., Huybrechts, P., Jugie, G., Johnsen, S. J., Jouzel, J., Kaufmann, P., Kipfstuhl, J., Lambert, F., Lipenkov, V. Y., Littot, G. C., Longinelli, A., Lorrain, R., Maggi, V., Masson-Delmotte, V., Miller, H., Mulvaney, R., Oerlemans, J., Oerter, H., Orombelli, G., Parrenin, F., Peel, D. A., Petit, J.-R., Raynaud, D., Ritz, C., Ruth, U., Schwander, J., Siegenthaler, U., Souchez, R., Stauffer, B., Steffensen, J. P., Stenni, B., Stocker, T. F., Tabacco, I. E., Udisti, R., van de Wal, R. S. W., van den Broeke, M., Weiss, J., Wilhelms, F., Winther, J.-G., Wolff, E. W., and Zucchelli, M.: 8 glacial cycles from an Antarctic ice core, Nature, 429, 623-628, 2004.

Gao, C., Robock, A., Self, S., Witter, J. B., Steffenson, J. P., Clausen, H. B., Siggaard-Andersen, M.-L., Johnsen, S., Mayewski, P. A., and Ammann, C.: The 1452 or 1453 A.D. Kuwae eruption signal derived from multiple ice core records: Greatest volcanic sulfate event of the past 700 years, J. Geophys. Res., 111, 1-11, 2006.

Gao, C., Robock, A., and Ammann, C.: Volcanic forcing of climate over the past 1500 years: An improved ice core-based index for climate models, J. Geophys. Res., 113, D23111,
doi:10.1029/2005JD006710, 2008.

Gazeaux, J., Batista, D., Ammann, C. M., Naveau, P., Jégat, C., and Gao, C.: Extracting common pulse-like signals from multiple ice core time series, Comput. Stat. Data An., in press, 2012.

Goujon, C., Barnola, J.-M., and Ritz, C.: Modeling the densification of polar firn including heat diffusion: application to closeoff characteristics and gas isotopic fractionation for Antarctica and Greenland sites, J. Geophys. Res., 108, ACL10/1-10, doi:10.1029/2002JD003319, 2003.

Hagemann, R. and Lohez, P.: Deuterium/hydrogen isotope ratio analysis, Adv. Mass Spetrom., 74, 504-509, 1978.

Jouzel, J., Lorius, C., Petit, J.-R., Genthon, C., Barkov, N. I., Kotlyakov, V., and Petrov, V. M.: Vostok ice core: A continuous isotope temperature record over the last climatic cycle $(160,000$ years), Nature, 329, 403-408, 1987.

Jouzel, J., Masson, V., Cattani, O., Falourd, S., Stievenard, M., Stenni, B., Longinelli, A., Johnsen, S., Steffenssen, J., Petit, J., Schwander, J., Souchez, R., and Barkov, N. I.: A new 27 kyr high resolution East Antarctic climate record, Geophys. Res. Lett., 28, 3199-3202, 2001.

Jouzel, J., Masson-Delmotte, V., Cattani, O., Dreyfus, G., Falourd, S., Hoffmann, G., Minster, B., Nouet, J., Barnola, J. M., Chappellaz, J., Fischer, H., Gallet, J. C., Johnsen, S., Leuenberger, M., Loulergue, L., Luethi, D., Oerter, H., Parrenin, F., Raisbeck, G., Raynaud, D., Schilt, A., Schwander, J., Selmo, E., Souchez, R., Spahni, R., Stauffer, B., Steffensen, J. P., Stenni, B., Stocker, T. F., Tison, J. L., Werner, M., and Wolff, E. W.: Orbital and Millennial Antarctic Climate Variability over the Past 800,000 Years, Science, 317, 793-796, 2007.

Kawamura, K., Parrenin, F., Uemura, R., Vimeux, F., Severinghaus, J. P., Matsumoto, K., Nakata, H., Nakazawa, T., Aoki, S., Jouzel, J., Fujii, Y., and Watanabe, O.: Northern Hemisphere forcing of climatic cycles over the past 360,000 years implied by absolute dating of Antarctic ice cores, Nature, 448, 912-917, 2007.

Laepple, T., Werner, M., and Lohmann, G.: Synchronicity of Antarctic temperatures and local solar insolation on orbital timescales, Nature, 471, 91-94, 2011.

Lorius, C., Jouzel, J., Ritz, C., Merlivat, L., Barkov, N., Korotkevitch, Y., and Kotlyakov, V.: A 150,000-years climatic record from Antarctic ice, Nature, 316, 591-596, 1985.

Masson-Delmotte, V., Buiron, D., Ekaykin, A., Frezzotti, M., Gallée, H., Jouzel, J., Krinner, G., Landais, A., Motoyama, H., Oerter, H., Pol, K., Pollard, D., Ritz, C., Schlosser, E., Sime, L. C., Sodemann, H., Stenni, B., Uemura, R., and Vimeux, F.: A comparison of the present and last interglacial periods in six Antarctic ice cores, Clim. Past, 7, 397-423, doi:10.5194/cp-7397-2011, 2011.

Narcisi, B., Petit, J.-R., and Tiepolo, M.: A volcanic marker (92 ka) for dating deep east Antarctic ice cores, Quaternary Sci. Rev., 25, 2682-2687, 2006.

Ninkovich, D., Shackleton, N. J., Abdel-Monem, A. A., Obradovich, J. D., and Izett, G.: K-Ar age of the Pleistocene eruption of Toba, north Sumatra, Nature, 276, 574-577, 1978.

Parrenin, F., Remy, F., Ritz, C., Siegert, M., and Jouzel, J.: New modelling of the Vostok ice flow line and implication for the glaciological chronology of the Vostok ice core, J. Geophys. Res., 109, D20102, doi:10.1029/2004JD004561, 2004.

Parrenin, F., Dreyfus, G., Durand, G., Fujita, S., Gagliardini, O., Gillet, F., Jouzel, J., Kawamura, K., Lhomme, N., Masson- 
Delmotte, V., Ritz, C., Schwander, J., Shoji, H., Uemura, R., Watanabe, O., and Yoshida, N.: 1-D-ice flow modelling at EPICA Dome C and Dome Fuji, East Antarctica, Clim. Past, 3, 243-259, doi:10.5194/cp-3-243-2007, 2007a.

Parrenin, F., Barnola, J.-M., Beer, J., Blunier, T., Castellano, E., Chappellaz, J., Dreyfus, G., Fischer, H., Fujita, S., Jouzel, J., Kawamura, K., Lemieux-Dudon, B., Loulergue, L., MassonDelmotte, V., Narcisi, B., Petit, J.-R., Raisbeck, G., Raynaud, D., Ruth, U., Schwander, J., Severi, M., Spahni, R., Steffensen, J. P., Svensson, A., Udisti, R., Waelbroeck, C., and Wolff, E.: The EDC3 chronology for the EPICA Dome C ice core, Clim. Past, 3, 485-497, doi:10.5194/cp-3-485-2007, $2007 \mathrm{~b}$.

Petit, J. R., Jouzel, J., Raynaud, D., Barkov, N. I., Barnola, J.-M., Basile, I., Bender, M., Chappellaz, J., Devis, M., Delaygue, G., Delmotte, M., Kotlyakov, V. M., Legrand, M., Lipenkov, V. Y., Lorius, C., Pepin, L., Ritz, C., Saltzman, E., and Stievenard, M.: Climate and atmospheric history of the past 420,000 years from the Vostok ice core, Antarctica, Nature, 399, 429-436, 1999.

Petraglia, M., Korisettar, R., Boivin, N., Clarkson, C., Ditchfield, P., Jones, S., Koshy, J., Lahr, M. M., Oppenheimer, C., Pyle, D., Roberts, R., Schwenninger, J.-L., Arnold, L., and White, K.: Middle Paleolithic Assemblages from the Indian Subcontinent Before and After the Toba Super-Eruption, Science, 317, 114116, 2007.

Raisbeck, G. M., Yiou, F., Jouzel, J., and Stocker, T. F.: Direct north-south synchronization of abrupt climate change record in ice cores using Beryllium 10, Clim. Past, 3, 541-547, doi:10.5194/cp-3-541-2007, 2007.

Rasmussen, S., Seierstad, I., Andersen, K., Bigler, M., Dahl-Jensen, D., and Johnsen, S.: Synchronization of the NGRIP, GRIP, and GISP2 ice cores across MIS 2 and palaeoclimatic implications, Quaternary Sci. Rev., 27, 18-28, 2008.

Robock, A., Ammann, C. M., Oman, L., Shindell, D., Levis, S., and Stenchikov, G.: Did the Toba volcanic eruption of $\sim 74$ ka B.P. produce widespread glaciation?, J. Geophys. Res., 114, D10107, doi:10.1029/2008JD011652, 2009.

Salamatin, A. N., Tsyganova, E. A., Popov, S. V., and Lipenkov, V. Y.: Ice flow line modeling in ice core data interpretation: Vostok Station (East Antarctica), in: Physics of Ice Core Records 2, edited by: Hondoh, T., Hokkaido University Press, Sapporo, 2009a.

Salamatin, A. N., Lipenkov, V. Y., Barnola, J. M., Hori, A., Duval, P., and Hondoh, T.: Snow-firn densification in polar ice sheets, in: Physics of Ice Core Records 2, edited by: Hondoh, T., Hokkaido University Press, Sapporo, 2009b.

Severi, M., Becagli, S., Castellano, E., Morganti, A., Traversi, R., Udisti, R., Ruth, U., Fischer, H., Huybrechts, P., Wolff, E., Parrenin, F., Kaufmann, P., Lambert, F., and Steffensen, J. P.: Synchronisation of the EDML and EDC ice cores for the last 52 kyr by volcanic signature matching, Clim. Past, 3, 367-374, doi:10.5194/cp-3-367-2007, 2007.

Siddall, M., Milne, G. A., and Masson-Delmotte, V.: Uncertainties in elevation changes and their impact on Antarctic temperature records since the end of the last glacial period, Earth Planet. Sci. Lett., 315-316, 12-23, 2012.

Sime, L. C., Wolff, E. W., Oliver, K. I. C., and Tindall, J. C.: Evidence for warmer interglacials in East Antarctic ice cores, Nature, 462, 342-345, 2009.
Stenni, B., Masson-Delmotte, V., Selmo, E., Oerter, H., Meyer, H., Röthlisberger, R., Jouzel, J., Cattani, O., Falourd, S., Fischer, H., Hoffmann, G., Iacumin, P., Johnsen, S., Minster, B., and Udisti, R.: The deuterium excess records of EPICA Dome C and Dronning Maud Land ice cores (East Antarctica), Quaternary Sci. Rev., 29, 146-159, 2010.

Stocker, T. F. and Johnsen, S. J.: A minimum thermodynamic model for the bipolar seesaw, Paleoceanography, 18, 1-9, 2003.

Svensson, A., Andersen, K. K., Bigler, M., Clausen, H. B., DahlJensen, D., Davies, S. M., Johnsen, S. J., Muscheler, R., Parrenin, F., Rasmussen, S. O., Röthlisberger, R., Seierstad, I., Steffensen, J. P., and Vinther, B. M.: A 60000 year Greenland stratigraphic ice core chronology, Clim. Past, 4, 47-57, doi:10.5194/cp-4-472008, 2008.

Udisti, R., Becagli, S., Castellano, E., Mulvaney, R., Schwander, J., Torcini, S., and Wolff, E. W.: Holocene electrical and chemical measurements from the EPICA-Dome $\mathrm{C}$ ice core, Ann. Glaciol., 30, 20-26, 2000.

Udisti, R., Becagli, S., Castellano, E., Delmonte, B., Jouzel, J., Petit, J.-R., Schwander, J., Stenni, B., and Wolff, E. W.: Stratigraphic correlations between the EPICA-Dome C and Vostok ice cores showing the relative variations of snow accumulation over the past 45 kyr, J. Geophys. Res., 109, D08101, doi:10.1029/2003JD004180, 2004.

Vasiliev, N., Talalay, P., Bobin, N., Chistyakov, V., Zubkov, V., Krasilev, A., Dmitriev, A., Yankilevich, S., and Lipenkov, V.: Deep drilling at Vostok station, Antarctica: history and recent events, Ann. Glaciol., 47, 10-23, 2007.

Vaughn, B., White, J. W. C., Delmotte, M., Trolier, M., Cattani, O., and Stievenard, M.: An automated system for the uranium reduction method of hydrogen isotope analysis of water, Chem. Geol., 152, 309-319, 1998.

Vinther, B. M., Clausen, H. B., Johnsen, S. J., Rasmussen, S. O., Andersen, K. K., Buchardt, S. L., Dahl-Jensen, D., Seierstad, I. K., Siggaard-Andersen, M.-L., Steffensen, J. P., Svensson, A., Olsen, J., and Heinemeier, J.: A synchronized dating of three Greenland ice cores throughout the Holocene, J. Geophys. Res., 111, 13102, doi:10.1029/2005JD006921, 2006.

Waelbroeck, C., Jouzel, J., Labeyrie, L., Lorius, C., Labracherie, M., and Stiévenard, M.: A comparison of the Vostok ice deuterium record and series from Southern Ocean core MD 88-770 over the last two glacial-interglacial cycles, Clim. Dynam., 12, 113-123, 1995.

Waelbroeck, C., Franck, N., Jouzel, J., Parrenin, F., MassonDelmotte, V., and Genty, D.: Transferring absolute dating of the Last Interglacial sea level high stand to marine and ice core records, Earth Planet. Sci. Lett., 265, 183-194, 2008.

Watanabe, O., Jouzel, J., Johnsen, S., Parrenin, F., Shoji, H., and Yoshida, N.: Homogeneous climate variability across East Antarctica over the past three glacial cycles, Nature, 422, 509512, 2003.

Westaway, R., Mishra, S., Deo, S., and Bridgland, D.: Methods for determination of the age of Pleistocene tephra, derived from eruption of Toba, in central India, J. Earth Sys. Sci., 120, 503530, 2011.

Westgate, J. A., Shane, P. A. R., Pearce, N. J. G., Perkins, W. T., Korisettar, R., Chesner, C. A., Williams, M. A. J., and Acharyya, S K.: All Toba Tephra Occurrences across Peninsular India Belong to the 75,000 yr B.P. Eruption, Quaternary Res., 50, 107-112, 
1998.

Williams, M. A., Ambrose, S. H., van der Kaars, S., Ruehlemann, C., Chattopadhyaya, U., Pal, J., and Chauhan, P. R.: Environmental impact of the $73 \mathrm{ka}$ Toba super-eruption in South Asia, Palaeogeogr., Palaeoclim., 284, 295-314, 2009.

Williams, M.: Did the 73 ka Toba super-eruption have an enduring effect? Insights from genetics, prehistoric archaeology, pollen analysis, stable isotope geochemistry, geomorphology, ice cores, and climate models, Quaternary. Int., in press, 2011.

Wolff, E. W.: Electrical stratigraphy of polar ice cores: principles, methods, and findings, in : Physics of Ice Core Records, edited by: Hondoh, T., Hokkaido University Press, Sapporo, 462-468, 2000 .
Wolff, E. W., Basile, I., Petit, J. R., and Schwander, J.: Comparison of Holocene electrical records from Dome C and Vostok, Ann. Glaciol., 29, 89-93, 1999.

Wolff, E. W., Cook, E., Barnes, P., and Mulvaney, R.: Signal variability in replicate ice cores, J. Glaciol., 51, 462-468, 2005.

Zielinski, G. A., Mayewski, P. A., and Taylor, K.: Potential atmospheric impact of the Toba mega-eruption 71,000 years ago, Geophys. Res. Lett., 23, 837, doi:10.1029/96GL00706, 1996. 